\title{
The influence of climatic conditions changes on grain yield in Winter Triticale (X Triticosecale Wittm.)
}

\author{
Ionuț RACZ ${ }^{1 *}$, Rozalia KADAR ${ }^{1}$, Adrian Ovidiu CECLAN ${ }^{1}$, Adina VARADI ${ }^{1,2}$, Andrei VARGA ${ }^{1,2}$, Felicia
} CHEŢAN $^{1}$

${ }^{1}$ Agricultural Research and Development Station Turda

${ }^{2}$ University of Agricultural Sciences and Veterinary Medicine Cluj-Napoca

*Corresponding author:racz_ionut@yahoo.com

Bulletin USAMV series Agriculture 74(1)/2017

Print ISSN 1843-5246; Electronic ISSN 1843-5386

DOI 10.15835/buasvmcn-agr: 12657

\begin{abstract}
The aim of this paper is making out the influence of climatic changes on grain yield of winter triticale in relation with applied fertilizer. The influence of environmental conditions on growing and development of triticale plants depends of grow stages and their duration. During five experimental years (2010-2015) the climatic conditions were different year to year, with an accentuated heating trend, influencing plant phenology, accelerating or slowing down some important processes disturbing grain yield formation. The influence of drought is more accentuated by heating stress and prolonging of these conditions during the main phenological processes have a negative influence on plant growth or development with effect on the grain yield formation process.
\end{abstract}

Keywords: grain yield, rainfall, temperature, winter triticale

\section{INTRODUCTION}

Significant achievement of modern genetics and plant breeding consist of creation of triticale, cultivars which successfully penetrate agricultural production (Shchipak et al., 2012). The increase of the sown area of the new grain and fodder crop is promoted by better compared to wheat (Triticum aestivum L.) adaptability, high and stable productivity, ample opportunities in grain use for food, technical and fodder purposes (Grabovets, 2000). Triticale (Triticosecale Witt.) is known as a plant with a large adaptability to climatic conditions, capable to produce high level of yield, even in poorer conditions.

Extreme weather events (high temperature and dryness), determine already a significant challenge for grain producers, are predicted to increase under future climate scenarios. Drought and high temperature are especially considered as key stress factors with high potential impact on crop yield (Kaur and Behl, 2010). Future climates will also be affected by greater variability in temperature and increased frequency of hot days (Pittock, 2003). The adaptation of new crop varieties to the climatic change need to understand how the crops respond to damage temperatures and how the reaction to heat can be improved (Halford, 2009).

Temperatures above the optimum for growth can be deleterious, causing damage or irreversible transformations, which is generally called 'heat stress' (Wahid et al., 2007). Heat stress is a function of the magnitude and rate of temperature increase, as well as the duration of exposure to the raised temperature (Wahid et al., 2007). 
Tab. 1. Climatic conditions of experimental years

\begin{tabular}{ccc}
\hline $\begin{array}{c}\text { Weather conditions/ } \\
\text { Experimental years }\end{array}$ & $\begin{array}{c}\text { Rainfall }(\mathbf{m m}) \\
\mathbf{5 7 \text { years }} \mathbf{5 2 0 . 5} \mathbf{~ m m}\end{array}$ & $\begin{array}{c}\text { Temperature }\left({ }^{0} \mathbf{C}\right) \\
57 \text { years }\end{array}$ \\
\hline $2010-2011$ & 592.4 & 9.37 \\
\hline $2011-2012$ & 409.4 & 9.88 \\
\hline $2012-2013$ & 499.2 & 10.72 \\
\hline $2013-2014$ & 600.0 & 10.92 \\
\hline $2014-2015$ & 632.5 & 10.52 \\
\hline
\end{tabular}

The physiology of drought stress and the characterization and phenotyping of drought resistance have greatly advanced in recent years (Araus et al., 2002; Blum, 2011; Reynolds et al., 2012). The potential yield of any cereal as well as triticale has an important impact on its performance under moderate stress. For drought stress the effect on yield performance takes place where cereal yield is subjected to moderate stress which does not reduce yield to below 30 to $50 \%$ of the potential (Blum, 2005). Where yield is reduced much more that level, specific genes for resistance are evidently expressed and become relevant for express potential yield. At times, yield maintenance at this sever stress level may come at the expense of the genetic yield potential (Blum, 2014). Resistance of the reproductive functions under low plant water status is crucial when stress occurs at flowering.

Resistance can be controlled by turgor maintenance, carbon supply, hormonal regulation or certain constitutive traits of the gametophyte (Dolferus et al., 2011; Firon et al., 2012). Delayed senescence of the canopy after flowering can be important in supporting grain filling (Thomas and Howarth, 2000). Finally, a superior capacity for stem reserve utilization for grain filling under drought or heat stress is a major tolerance mechanism under terminal stress (Yang and Zhang, 2006). Any of the above resistance mechanisms might involve constitutive or adaptive plant traits and processes. These traits and functions are crucial for evaluating the relative drought resistance of crops and genotypes in experimental work. Beyond all of the above there are also issues of adapting plant phenology to the water regime and the questionable value of plant survival under extreme desiccation which might be important in certain agro-ecological or even social situations.
Growth and development of triticale plants can be substantial influenced by the parameters of climatic conditions, especially drought and temperature. These are considered as key stress factors with high potential impact on crop grain yield.

\section{MATERIALS AND METHODS}

Eight Romanian winter triticale cultivars adapted to local conditions were used to study the effect of temperature variation and available water in relationship with plant growth stages.

The aim of this study were to determine the behavior of biological material regarding grain yield in relationship with environmental factors (rainfall and temperature) in different growth plant stages during 2010-2015.

- experimental design: randomized block

- two doses of fertilizations (basic N:P/50:50 applied at plant emergence; additional-N/50 applied at plant stem elongation stage.)

- the experimental data were capitalize based on correlation/regression method between grain yield and climatic conditions (rainfall and temperature) for a timing period during the main phenological stages.

The analysis of winter triticale grain yield ability during the last five years was made with emphases on continue global warming process. So, the multiannual mean temperature (55 years) was $8.94{ }^{\circ} \mathrm{C}$ and in those five experimental years increased worry. The real concern regarding the annual mean temperature for last five years is related to increase of these with almost 1.5-2 ${ }^{\circ} \mathrm{C}$ (Tab. 1). During this five experimental years the rainfall conditions were generally up to the multiannual mean (520.5 mm) except 2011-2012 (409.4 mm) and 2012-2013 when the rainfall can be appreciate as being close to this (499.2 $\mathrm{mm})$. 


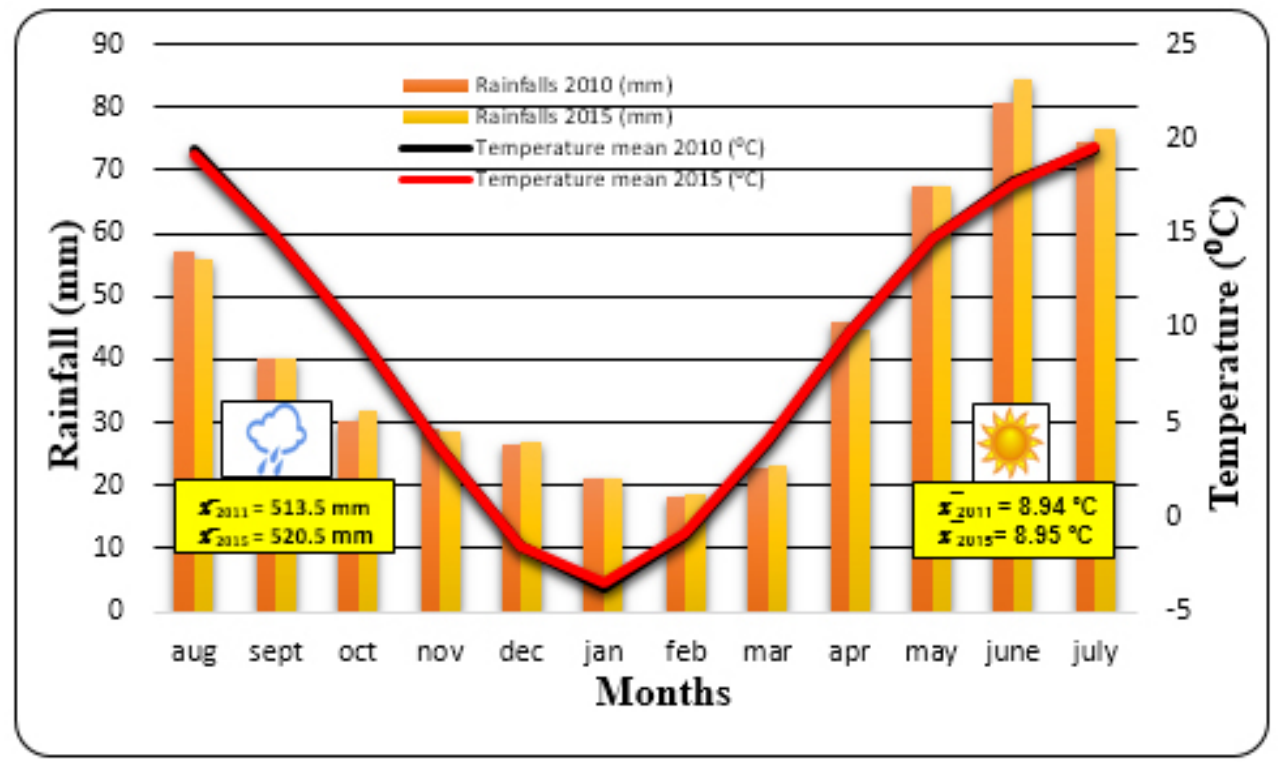

Fig. 1. The multiannual mean of temperature and rainfall from 2010 and 2015

Regarding climatic conditions during the winter triticale growth season, temperatures are nearly similar between multiannual mean from 2010-2011 and 2014-2015, with some elevated value early in the growth stages witch determine the acceleration of physiological processes. About rainfall, even if those are improved $(520.5 \mathrm{~mm}$ for $2014 / 2015$ as against $513.5 \mathrm{~mm}$ for $2010 / 2011$ Fig. 1) their dispersion is uncorrelated with the plant needs, at least in May when in plant occurring important morpho-physiological processes with high impact on grain yield. A frequent and undesirable fact during the second vegetation period (which occur generally in May and June) are rainfall intensity and short-duration of these with other storm characteristics.

This type of rain (quantitative significant but short- duration) are unable to support well growth and development because of availability discontinuous of soil water content.

\section{RESULTS AND DISCUSSIONS}

During this five experimental years the grain yield performance it was quite stable (Tab.1), there are visible differences both between experimental years and fertilization level. As a classification for experimental year favorability winter triticale growth and yields conditions can be observed first experimental year as the poorest in contrast with fourth experimental year where the grain yield values were the highest, during the experiment.

Analyzing the genotypes behavior during the study for every experimental factors (year and fertilization), Cascador $\mathrm{F}$ variety can be mention for negative grain yield performance in poor conditions, in the first experimental year at basic fertilization (3600 $\mathrm{kg} \mathrm{ha}^{-1}$ ); and also for its high capacity to capitalize favorable environmental conditions- fourth experimental year at additional fertilization (9725 $\left.\mathrm{kg} \mathrm{ha}^{-1}\right)$. This large grain yield amplitude of Cascador $F$ variety suggest a high dependence on the growth environmental conditions. Another aspect which must be painted out is the average performance of Plai variety, which in this five experimental years have realize the higher grain yield both at basic fertilization and additional fertilization.

The main climatic factors (rainfall and temperature) have an important contribution or influence on winter triticale grain yield. Throughout the experimental period, the rainfall conditions varied from $409.4 \mathrm{~mm}$ precipitation (2012) to $632.5 \mathrm{~mm}$ (2015) having an insignificant influence on grain yield both on basic and additional fertilization (Fig. 2). At the same time, the relationship between continuous increase of annual means temperature and grain yields is quite close being significant for temperature and grain yield at basic fertilization $\left(0.86^{*}\right)$, and much stronger at additional fertilization $\left(0.91^{* *}\right)$. 
Tab. 2.Winter triticale grain yield (kg/ha) during five experimental years at two fertilization levels (a - basic fertilization; b- additional fertilization)

\begin{tabular}{|c|c|c|c|c|c|c|c|c|c|c|c|c|}
\hline \multirow{2}{*}{$\begin{array}{c}\text { Year/ } \\
\text { Variety }\end{array}$} & \multicolumn{2}{|c|}{2011} & \multicolumn{2}{|c|}{2012} & \multicolumn{2}{|c|}{2013} & \multicolumn{2}{|c|}{2014} & \multicolumn{2}{|c|}{2015} & \multicolumn{2}{|c|}{ Average } \\
\hline & $\mathrm{a}$ & $\mathrm{b}$ & $\mathrm{a}$ & $\mathrm{b}$ & $\mathrm{a}$ & $\mathrm{b}$ & $\mathrm{a}$ & $\mathrm{b}$ & $\mathrm{a}$ & $\mathrm{b}$ & $\mathrm{a}$ & $\mathrm{b}$ \\
\hline Plai & 4876 & 5380 & 5220 & 6244 & 6343 & 7456 & 7880 & 9243 & 7321 & 8422 & 6328 & $\underline{7349}$ \\
\hline Titan & 4187 & 5017 & 4546 & 5838 & 4976 & 7160 & 8144 & 9060 & 6063 & 7012 & 5583 & 6817 \\
\hline Stil & 4276 & 5068 & 4512 & 5925 & 4819 & 6511 & 7805 & 9314 & 6675 & 7420 & 5617 & 6848 \\
\hline Haiduc & 4343 & 5655 & 4826 & 6189 & 5609 & 6847 & 7434 & 9224 & 6686 & 8088 & 5780 & 7201 \\
\hline Cascador F & 3600 & 4930 & 4812 & 5929 & 5419 & 6724 & 7306 & $\underline{9725}$ & 5775 & 6839 & 5382 & 6829 \\
\hline Negoiu & 4486 & 5330 & 4957 & 5839 & 5531 & 7280 & 6169 & 8528 & 6838 & 8136 & 5596 & 7023 \\
\hline Oda & 4497 & 5198 & 4841 & 6024 & 5845 & 6892 & 8105 & 9506 & 6094 & 6991 & 5876 & 6922 \\
\hline TF 2 & 4294 & 4579 & 4484 & 5824 & 5435 & 6932 & 7098 & 8615 & 7336 & 8004 & 5729 & 6791 \\
\hline Mean & 4320 & 5145 & 4775 & 5977 & 5497 & 6975 & 7493 & 9152 & 6599 & 7614 & 5736 & 6973 \\
\hline
\end{tabular}

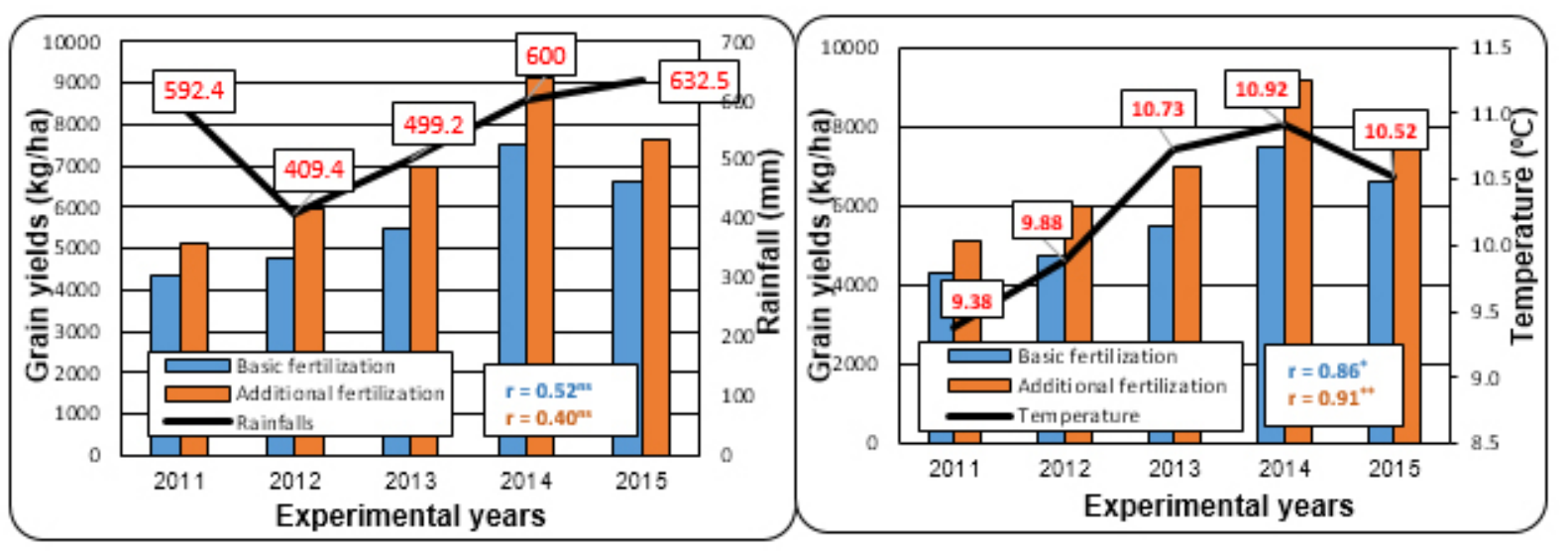

Fig. 2. Relationship between annual mean rainfall/temperature and grain yield for winter triticale

Tab. 3. Correlation between grain yield and rainfall during growth and development stages on winter triticale plants at two levels fertilization (a- basic fertilization; b- additional fertilization)

\begin{tabular}{|c|c|c|c|c|c|c|c|c|c|c|c|c|c|c|}
\hline \multirow{2}{*}{ Var./month } & \multicolumn{2}{|c|}{ Oct. } & \multicolumn{2}{|c|}{ Nov. } & \multicolumn{2}{|c|}{ Dec. } & \multicolumn{2}{|c|}{ Apr. } & \multicolumn{2}{|c|}{ May } & \multicolumn{2}{|c|}{ June } & \multicolumn{2}{|c|}{ July } \\
\hline & $\mathrm{a}$ & $\mathrm{b}$ & $\mathrm{a}$ & $\mathrm{b}$ & a & $\mathrm{b}$ & $\mathrm{a}$ & $\mathrm{b}$ & $\mathrm{a}$ & $\mathrm{b}$ & $\mathrm{a}$ & $\mathrm{b}$ & a & $\mathrm{b}$ \\
\hline Plai & 0.70 & 0.62 & -0.02 & -0.12 & 0.10 & 0.04 & 0.28 & 0.37 & 0.11 & 0.22 & -0.34 & -0.42 & 0.11 & 0.06 \\
\hline Titan & 0.68 & 0.50 & -0.18 & -0.35 & -0.24 & -0.24 & 0.44 & 0.60 & 0.02 & 0.24 & -0.55 & -0.63 & 0.43 & 0.20 \\
\hline Stil & $0.77^{*}$ & 0.61 & 0.00 & -0.24 & -0.04 & -0.21 & 0.25 & 0.49 & -0.03 & 0.16 & -0.39 & -0.58 & 0.35 & 0.29 \\
\hline Haiduc & 0.69 & 0.69 & -0.07 & -0.10 & 0.02 & 0.05 & 0.32 & 0.35 & 0.12 & 0.10 & -0.40 & -0.45 & 0.17 & 0.24 \\
\hline Cascador F & 0.48 & 0.51 & -0.36 & -0.38 & -0.22 & -0.37 & 0.58 & 0.63 & 0.32 & 0.19 & -0.65 & -0.70 & 0.14 & 0.34 \\
\hline Negoiu & 0.65 & 0.65 & 0.19 & -0.03 & 0.43 & 0.15 & -0.01 & 0.29 & 0.17 & 0.18 & -0.06 & -0.32 & -0.18 & 0.01 \\
\hline Oda & 0.61 & 0.52 & -0.26 & -0.36 & -0.26 & -0.34 & 0.53 & 0.62 & 0.10 & 0.19 & -0.59 & -0.68 & 0.35 & 0.01 \\
\hline TF 2 & $0.77^{*}$ & 0.57 & 0.18 & -0.15 & 0.29 & 0.06 & 0.06 & 0.37 & 0.03 & 0.29 & -0.15 & -0.42 & 0.06 & -0.02 \\
\hline
\end{tabular}

Monthly rainfall have a great influence on grain yield especially when there are comes in important phenological stages. Analyzing the relationship between monthly rainfall during the entire vegetation period of triticale and its grain yield (Tab. 3) can be observed the importance of water availability in the early vegetative stages and his influence on the final grain yield. 
Tab. 4. Correlation between grain yield and temperature during growth and development stages on winter triticale plants at two levels fertilization (a- basic fertilization; b- additional fertilization)

\begin{tabular}{|c|c|c|c|c|c|c|c|c|c|}
\hline Var./mc & & Oct & Nov & Dec & Mar & Apr & May & June & July \\
\hline \multirow{2}{*}{ Plai } & $\mathrm{a}$ & $0.86^{*}$ & 0.35 & 0.01 & 0.61 & -0.22 & -0.37 & -0.61 & -0.20 \\
\hline & $\mathrm{b}$ & $0.89 * *$ & 0.26 & 0.02 & 0.59 & -0.14 & -0.32 & -0.54 & -0.13 \\
\hline \multirow{2}{*}{ Titan } & $\mathrm{a}$ & 0.67 & 0.37 & -0.07 & $0.86^{*}$ & -0.13 & -0.62 & -0.63 & -0.26 \\
\hline & $\mathrm{b}$ & $0.86^{*}$ & 0.27 & -0.23 & 0.65 & 0.13 & -0.32 & -0.57 & -0.25 \\
\hline \multirow{2}{*}{ Stil } & $\mathrm{a}$ & 0.66 & 0.38 & 0.09 & $0.82^{*}$ & -0.33 & -0.63 & -0.61 & -0.19 \\
\hline & $\mathrm{b}$ & $0.77^{*}$ & 0.27 & -0.04 & $0.77^{*}$ & -0.07 & -0.50 & -0.56 & -0.17 \\
\hline \multirow{2}{*}{ Haiduc } & $\mathrm{a}$ & $0.82^{*}$ & 0.32 & 0.04 & 0.68 & -0.22 & -0.43 & -0.58 & -0.16 \\
\hline & $\mathrm{b}$ & $0.78^{*}$ & 0.32 & 0.03 & 0.74 & -0.20 & -0.50 & -0.59 & -0.17 \\
\hline \multirow{2}{*}{ Cascador F } & $\mathrm{a}$ & $0.84^{*}$ & 0.14 & -0.05 & 0.66 & 0.06 & -0.34 & -0.46 & -0.09 \\
\hline & $\mathrm{b}$ & $0.75^{*}$ & 0.26 & -0.19 & $0.77^{*}$ & 0.11 & -0.46 & -0.56 & -0.23 \\
\hline \multirow{2}{*}{ Negoiu } & $\mathrm{a}$ & $0.80^{*}$ & 0.19 & 0.32 & 0.37 & -0.45 & -0.21 & -0.38 & 0.06 \\
\hline & $\mathrm{b}$ & $0.91^{* *}$ & 0.31 & 0.00 & 0.52 & -0.18 & -0.26 & -0.57 & -0.17 \\
\hline \multirow{2}{*}{ Oda } & $\mathrm{a}$ & $0.77^{*}$ & 0.37 & -0.21 & $0.76^{*}$ & 0.02 & -0.48 & -0.65 & -0.32 \\
\hline & $\mathrm{b}$ & $0.77^{*}$ & 0.27 & -0.20 & $0.76^{*}$ & 0.10 & -0.45 & -0.58 & -0.25 \\
\hline \multirow{2}{*}{ TF 2} & $\mathrm{a}$ & $0.78^{*}$ & 0.36 & 0.19 & 0.57 & -0.44 & -0.40 & -0.56 & -0.12 \\
\hline & $\mathrm{b}$ & $0.90^{* *}$ & 0.17 & 0.08 & 0.54 & -0.13 & -0.26 & -0.46 & -0.04 \\
\hline
\end{tabular}

Tab. 5. Correlation between winter triticale grain yield and rainfall during the main growth and development stages of plants (a- basic fertilization; $b$ - additional fertilization)

\begin{tabular}{|c|c|c|c|c|c|c|c|c|c|c|c|c|c|c|c|}
\hline \multirow{2}{*}{\multicolumn{2}{|c|}{$\begin{array}{c}\text { Month/ variety } \\
\text { I }\end{array}$}} & \multicolumn{3}{|c|}{ March } & \multicolumn{3}{|c|}{ April } & \multicolumn{3}{|c|}{ May } & \multicolumn{3}{|c|}{ June } & \multirow{2}{*}{\multicolumn{2}{|c|}{ July }} \\
\hline & & II & III & I & II & III & I & II & III & I & II & III & I & & \\
\hline \multirow{2}{*}{ Plai } & $\mathrm{a}$ & 0.38 & 0.05 & 0.21 & -0.01 & 0.17 & 0.24 & 0.36 & 0.11 & $\begin{array}{l}-0.10 \\
\end{array}$ & -0.62 & 0.24 & -0.14 & 0.70 & -0.15 \\
\hline & $\mathrm{b}$ & 0.40 & 0.04 & 0.24 & 0.08 & 0.21 & 0.29 & 0.27 & 0.22 & -0.01 & -0.62 & 0.25 & -0.25 & 0.69 & -0.10 \\
\hline \multirow{2}{*}{ Titan } & $\mathrm{a}$ & 0.15 & -0.02 & 0.00 & -0.13 & 0.52 & 0.30 & 0.51 & 0.19 & -0.28 & -0.66 & 0.02 & -0.16 & $0.82 *$ & 0.20 \\
\hline & $\mathrm{b}$ & 0.46 & 0.21 & 0.33 & 0.21 & 0.43 & 0.19 & 0.23 & 0.30 & 0.00 & -0.46 & -0.01 & -0.36 & $0.84^{*}$ & 0.07 \\
\hline \multirow{2}{*}{ Stil } & $\mathrm{a}$ & 0.10 & -0.14 & -0.08 & -0.25 & 0.36 & 0.35 & 0.56 & 0.10 & -0.31 & -0.74 & 0.19 & -0.05 & 0.71 & 0.08 \\
\hline & $\mathrm{b}$ & 0.24 & 0.00 & 0.09 & $\begin{array}{l}-0.01 \\
\end{array}$ & 0.47 & 0.34 & 0.38 & 0.28 & -0.14 & -0.65 & 0.10 & -0.27 & $0.79 *$ & 0.15 \\
\hline \multirow{2}{*}{ Haiduc } & $\mathrm{a}$ & 0.30 & -0.02 & 0.13 & -0.05 & 0.26 & 0.31 & 0.39 & 0.16 & -0.13 & -0.68 & 0.23 & -0.17 & 0.71 & -0.05 \\
\hline & $\mathrm{b}$ & 0.24 & -0.04 & 0.07 & -0.08 & 0.34 & 0.33 & 0.43 & 0.18 & -0.17 & -0.70 & 0.19 & -0.17 & 0.74 & 0.04 \\
\hline \multirow{2}{*}{$\begin{array}{c}\text { Cascador } \\
\mathrm{F}\end{array}$} & $\mathrm{a}$ & 0.35 & 0.04 & 0.22 & 0.17 & 0.44 & 0.36 & 0.21 & 0.40 & 0.05 & -0.59 & 0.14 & -0.42 & $0.75^{*}$ & 0.13 \\
\hline & $\mathrm{b}$ & 0.30 & 0.11 & 0.17 & 0.10 & 0.58 & 0.27 & 0.32 & 0.34 & -0.10 & -0.53 & -0.06 & -0.35 & $0.86^{*}$ & 0.24 \\
\hline \multirow{2}{*}{ Negoiu } & $\mathrm{a}$ & 0.30 & -0.17 & 0.12 & $\begin{array}{l}-0.07 \\
\end{array}$ & -0.15 & 0.37 & 0.25 & 0.07 & 0.02 & -0.70 & 0.58 & $\begin{array}{l}-0.08 \\
\end{array}$ & 0.36 & -0.34 \\
\hline & $\mathrm{b}$ & 0.46 & 0.09 & 0.30 & 0.08 & 0.10 & 0.22 & 0.27 & 0.13 & -0.01 & -0.57 & 0.27 & -0.18 & 0.67 & -0.22 \\
\hline \multirow{2}{*}{ Oda } & $\mathrm{a}$ & 0.34 & 0.16 & 0.20 & 0.04 & 0.48 & 0.19 & 0.39 & 0.21 & -0.17 & -0.52 & -0.06 & -0.24 & $0.88^{* *}$ & 0.12 \\
\hline & $\mathrm{b}$ & 0.32 & 0.13 & 0.20 & 0.11 & 0.55 & 0.25 & 0.32 & 0.32 & -0.10 & -0.52 & -0.05 & -0.34 & $0.86^{*}$ & 0.20 \\
\hline \multirow{2}{*}{ TF 2} & $\mathrm{a}$ & 0.26 & -0.10 & 0.07 & -0.17 & 0.02 & 0.29 & 0.43 & 0.00 & -0.17 & -0.72 & 0.40 & 0.00 & 0.55 & -0.24 \\
\hline & $\mathrm{b}$ & 0.40 & 0.00 & 0.24 & 0.12 & 0.18 & 0.35 & 0.20 & 0.27 & 0.07 & 0.64 & 0.33 & -0.30 & 0.63 & -0.10 \\
\hline
\end{tabular}

The significant influence of rainfall from October $\left(0.77^{*}\right.$ at Stil and TF 2 varieties; for basic fertilization) can be explained through the importance of the productivity component which is establish in this period- number of plants/unit area. Thus, the lack of significant influences of 
Tab. 6. Correlation between winter triticale grain yield and temperature during the main growth and development stages of plants (a -basic fertilization; $\mathrm{b}$-additional fertilization)

\begin{tabular}{|c|c|c|c|c|c|c|c|c|c|c|c|c|c|c|c|}
\hline \multirow{2}{*}{\multicolumn{2}{|c|}{$\begin{array}{c}\text { Month/ } \\
\text { variety } \\
\text { I } \\
\end{array}$}} & \multicolumn{3}{|c|}{ March } & \multicolumn{3}{|c|}{ April } & \multicolumn{3}{|c|}{ May } & \multicolumn{3}{|c|}{ June } & \multicolumn{2}{|c|}{ July } \\
\hline & & II & III & I & II & III & I & II & III & I & II & III & I & II & \\
\hline \multirow{2}{*}{ Plai } & $\mathrm{a}$ & $92^{* *}$ & -0.05 & 0.15 & -0.16 & 0.27 & -0.38 & 0.03 & -0.48 & -0.16 & -0.08 & -0.38 & -0.46 & -0.19 & -0.67 \\
\hline & $D$ & $3^{* *}$ & -0.09 & 0.13 & -0.16 & 0.33 & -0.31 & 0.11 & -0.52 & -0.24 & -0.14 & -0.31 & -0.36 & -0.11 & -0.72 \\
\hline \multirow{2}{*}{ Titan } & $\mathrm{a}$ & $0.84^{*}$ & 0.31 & 0.43 & 0.20 & -0.03 & -0.41 & -0.20 & $-0.77^{*}$ & 0.10 & -0.06 & -0.57 & -0.39 & -0.22 & -0.49 \\
\hline & b & 96 & 0.04 & 0.12 & 0.12 & 0.18 & -0.11 & 0.10 & -0.54 & -0.21 & -0.37 & -0.28 & -0.21 & -0.19 & $-0.76^{*}$ \\
\hline \multirow{2}{*}{ Stil } & $\mathrm{a}$ & $80^{*}$ & 0.24 & 0.45 & 0.02 & 0.04 & -0.57 & -0.22 & -0.64 & 0.11 & 0.12 & -0.61 & -0.52 & -0.17 & -0.43 \\
\hline & $\mathrm{b}$ & $89^{* *}$ & 0.17 & 0.34 & 0.10 & 0.11 & -0.33 & -0.04 & $-0.77^{*}$ & -0.0 & -0.13 & -0.44 & -0.31 & -0.13 & -0.60 \\
\hline \multirow{2}{*}{ Haiduc } & a & $0.90^{* *}$ & 0.03 & 0.24 & -0.10 & 0.23 & -0.41 & -0.01 & -0.56 & -0.12 & -0.05 & -0.42 & -0.44 & -0.14 & -0.62 \\
\hline & $\mathrm{b}$ & $88^{*}$ & 0.11 & 0.32 & -0.02 & 0.16 & -0.43 & -0.07 & -0.61 & -0.05 & -0.03 & -0.48 & -0.43 & -0.15 & -0.58 \\
\hline \multirow{2}{*}{ Cascador F- } & $\mathrm{a}$ & $0.91^{* *}$ & 0.02 & 0.22 & 0.04 & 0.26 & -0.18 & 0.14 & $-0.75^{*}$ & -0.23 & -0.26 & -0.27 & -0.17 & -0.04 & -0.72 \\
\hline & $\mathrm{b}$ & $0.89^{* *}$ & 0.21 & 0.30 & 0.25 & 0.05 & -0.18 & -0.02 & $-0.76^{*}$ & -0.07 & -0.29 & -0.39 & -0.20 & -0.17 & -0.63 \\
\hline \multirow{2}{*}{ Negoiu } & $\mathrm{a}$ & 0.74 & -0.30 & 0.08 & -0.53 & 0.51 & -0.48 & 0.15 & -0.39 & -0.28 & 0.15 & -0.25 & -0.49 & 0.03 & -0.58 \\
\hline & b & $0.93^{* *}$ & -0.16 & 0.04 & -0.24 & 0.37 & -0.31 & 0.13 & -0.42 & -0.27 & -0.14 & -0.28 & -0.42 & -0.16 & -0.74 \\
\hline \multirow{2}{*}{ Oda } & $\mathrm{a}$ & $0.93^{* *}$ & 0.20 & 0.25 & 0.19 & 0.04 & -0.25 & -0.07 & -0.57 & -0.04 & -0.24 & -0.44 & -0.32 & -0.27 & -0.64 \\
\hline & $\mathrm{b}$ & $0.91^{* *}$ & 0.19 & 0.27 & 0.23 & 0.06 & -0.18 & -0.01 & -0.76 & -0.09 & -0.29 & -0.38 & -0.22 & -0.19 & -0.65 \\
\hline \multirow{2}{*}{ TF 2} & a & $0.81^{*}$ & -0.08 & 0.20 & -0.32 & 0.30 & -0.55 & -0.04 & -0.44 & -0.10 & 0.14 & -0.44 & -0.58 & -0.14 & -0.54 \\
\hline & $\mathrm{b}$ & $0.91^{* *}$ & -0.16 & 0.11 & -0.22 & 0.41 & -0.28 & 0.19 & -0.54 & -0.31 & -0.14 & -0.24 & -0.31 & -0.02 & -0.74 \\
\hline
\end{tabular}

rainfall on winter triticale grain yield during the spring months (april-may-june) can be attributed to high roots development of plants, which are able to extract the nutritive substances from deep of soil.

Regarding the influence of temperature during growth and development triticale plants stages on the grain yield, the positive temperature from this period determined a significant and distinct significant correlation with grain yield for both fertilization levels at main varieties (Tab. 4). Another important influence on grain yield are express by temperatures from march for some varieties which can be attribute to early restarts of triticale plants and biomass accumulation. Also, high temperature from may-june affect grain yield both at additional fertilization and basic fertilization.

Analyzing the influence of month decade rainfall on final grain yield for the spring months when occur the main phenological plant stages, their significant influence on grain yield have the rainfall from July first decade (Tab. 5). Some important information about the role of water during the plant heading and anthesis are notable even if those data are not correlated (third decade of may and first decade from June).
Regarding the temperature influence during the plant growth and development stages (spring-summer period), their influence is more disruption because the importance of phenological development that occur this period. Positive temperature from the beginning of March is direct correlated with winter triticale grain yield for both levels of fertilizer (Tab. 6). Also, the impact of temperatures on triticale plant range if these occur before the anthesis stage because of its susceptibility in these stage. Generally, the increasing temperature affect the normal growth and development stages of triticale plant but this aspects are reduced by rustic and better adaptability of this species.

\section{CONCLUSION}

The influence of climatic conditions on winter triticale grain yield varieties revealed the effects of the temperature and precipitation in different stages of plants growing season.

Predictability of grain yield depends on the genetic value of each genotype, and their adaptability to adverse environmental conditions and specific production potential.

Rainfall from October and July can have an important contribution on final grain yield 
especially if those are associated with a normal temperature for this period.

Temperature during plant emergence and heading/flowering have a high positive influence on grain yield.

Even triticale is a very adaptable plant the short dryness period or high temperature can determine a substantial diminution of grain yield.

\section{REFERENCES}

1. Araus JL, Slafer GA, Reynolds MP, Royo C (2002). Plant breeding and drought in C3 cereals: What should we breed for?. Ann. Bot. 89:925-940.

2. Blum A (2011). Plant Breeding for Water Limited Environments. Springer. New York, USA, 258 pp.

3. Blum A. (2005). Drought resistance, water-use efficiency, and yield potential-are they compatible, dissonant, or mutually exclusive?. Australian Journal of Agricultural Research. 56: 1159-1168.

4. Dolferus R, Xuemei J, Richards RA (2011). Abiotic stress and control of grain number in cereals. Plant Sci. 181:331341.

5. Firon N, Nepi M, Pacini E (2012). Water status and associated processes mark critical stages in pollen development and functioning. Ann. Bot., 109:1201-1214.

6. Grabovets AI (1999). Triticale of Russia / Sbornik materialov sekcii tritikale RASHN: collection of materials of the triticale section of the Russian Academy of Agrarian Sciences (8-9 July, 1999). - Rostov-on-Don. - p. 132.

7. Halford NG (2009). New insights on the effects of heat stress on crops. J. Exper. Bot. 60: 4215-4216.

8. Kaur V, Behl RK (2010). Grain Yield in Wheat as Affected by Short Periods of High Temperature, Drought and their Interaction during Pre- and Post-anthesis Stages. Cereal Research Communications 38 (4), pp. 514-520.

9. Pittock B (2003). Climate Change: An Australian Guide to the Science and Potential of Impacts. Department for the Environment and Heritage. Australian Greenhouse Office. Canberra, ACT. http://www.greenhouse.gov.au/science/ guide/index.html.

10. Reynolds MP, Pask AJD, Mullan DM (2012). Physiological Breeding I: Interdisciplinary Approaches to Improve Crop Adaptation. Eds. CIMMYT, Mexico, D.F.

11. Shchipak GV, Yu V, Tsupko AP, Petrova VG, Shchipak (2012). Productivity, adaptability and grain quality of modern Ukrainian winter triticale cultivars. ВаВилоВский журнал генетики и селекции. Том 16, № 2, p. 464-470.

12. Thomas H, Howarth CJ (2000). Five ways to stay green. J. Exp. Bot. 51:329-337.

13. Wahid A, Gelani S, Ashraf M, Foolad MR (2007) Heat tolerance in plants: An overview. Environmental and Experimental Botany, 61: 199-223.

14. Yang J, Zhang J (2006). Grain filling of cereals under soil drying, New Phytol. 169:223-236. 